\title{
Expression of Specific Class I Chitinase mRNA Levels in Different Grape Varieties and Their Antimicrobial Activity
}

\author{
Jana Žiarovská ${ }^{1, *}$, Lucia Zamiešková ${ }^{1}$ (D) Jana Bilčíková ${ }^{2}$, Veronika Fialková ${ }^{2}$, Jozef Sabo ${ }^{3}$, \\ Simona Kunová ${ }^{4}$ and Miroslava Kačániová ${ }^{3,5}$ (D) \\ 1 Department of Plant Genetics and Breeding, Faculty of Agrobiology and Food Resources, Slovak University \\ of Agriculture, Tr. A. Hlinku 2, 94976 Nitra, Slovakia; xzamieskova@uniag.sk \\ 2 AgroBioTech Research Centre, Slovak University of Agriculture, Tr. A. Hlinku 2, 94976 Nitra, Slovakia; \\ jana.bilcikova@uniag.sk (J.B.); veronika.fialkova@uniag.sk (V.F.) \\ 3 Department of Fruit Science, Viticulture and Enology, Faculty of Horticulture and Landscape Engineering, \\ Slovak University of Agriculture, Tr. A. Hlinku 2, 94976 Nitra, Slovakia; sabododik@gmail.com (J.S.); \\ miroslava.kacaniova@gmail.com (M.K.) \\ 4 Department of Food Hygiene and Safety, Faculty of Biotechnology and Foods, Slovak University of \\ Agriculture, Tr. A. Hlinku 2, 94976 Nitra, Slovakia; simona.kunova@uniag.sk \\ 5 Department of Bioenergetics and Food Analysis, Faculty of Biology and Agriculture, University of Rzeszów, \\ Cwiklinskiej 1, 35-601 Rzeszow, Poland \\ * Correspondence: jana.ziarovska@uniag.sk; Tel.: +421-376-414-244
}

Received: 18 June 2020; Accepted: 7 August 2020; Published: 11 August 2020

\begin{abstract}
The aim of this study was to compare the natural variability of the expression of class I chitinase gene in grapes of Vitis vinifera L. varieties as well as investigate their antimicrobial activity. Further, the effect of antimicrobial activity in chitinase expression was analyzed. Matured berries of thirteen grape varieties were used in the study-Alibernet, Dornfelder, Cabernet Sauvignon, Blaufränkisch, Sauvignon Blanc, Welschriesling, Weisser Riesling, Irsai Oliver, Pinot Blanc, Pálava, Müller-Thurgau, Grúner Veltliner, and Feteasca Regala, grown in the Small Carpathians wine region of Slovakia, Vrbové. Chitinase I gene expression was found to be similar in most of the analyzed varieties with the except of two varieties, where the expression of chitinase I was significantly higher-Pinot Blanc and Savignon Blanc. By comparing the varieties between the lowest and highest expression fold change, they were statistically different in the level of its chitinase I gene expression. Grape pomace extracts of analyzed Vitis vinifera L. were effective against Gram-positive, Gram-negative bacteria and yeasts, but a weak correlation tendency was found between chitinase I gene expression and antimicrobial activity, only against Staphylococcus aureus subsp. aureus, Candida albicans, and Candida glabrata.
\end{abstract}

Keywords: chitinase I; mRNA level; expression; grape; antimicrobial activity

\section{Introduction}

Vitis vinifera L., belongs to the oldest cultivated plants and is well adapted to a wide range of climates. The best agroclimatic conditions for its growth are those of the temperate Mediterranean regions up to the continental areas in central Europe. Western Europe is the world's biggest producer of grapes and they are consumed either directly or as wine and the [1]. The health beneficial effects of grapes and wine consumption are well-known. Vitis vinifera $\mathrm{L}$. is valuable/rich source of polyphenols, flavonoids, anthocyanins, phenolic acids, stilbenes, vitamins (A and C), minerals (phosphorus, calcium), and carbohydrates [2,3]. Recently, it has been observed that moderate consumption of grapes or 
red wine has many health beneficial effects: anti-asthmatic, cardio-protective, cytotoxic, anti-aging, hepatoprotective, anti-inflammatory, antioxidant $[4,5]$. Vitis vinifera L. is a part of different research activities in omics sciences, too [6,7].

Plant resistance to biotic stress is a result of the defence mechanisms activation such as transcriptional activation of defence-related genes, deposition of mechanical barriers, accumulation of phytoalexins, and pathogenesis-related proteins synthesis [8]. Chitinases are one of the most complex characterized pathogen-related proteins and are reported to have a wide range of different roles in plants to serve many specific functions in embryogenesis and ethylene synthesis, in the response to environmental stresses $[9,10]$ and are involved in response to phytopathogen attack [11]. Endochitinases in plants are parts of stems, flowers, seeds, as well as tubers and they undergo hydrolyzation of internal -1,4-linkages of chitin that results in COS and GlcNAc [10]. Plant chitinases were found in many crop species such as pineapple, tomato, potato, oat, barley, corn, rice, beans, pea, peanut, cabbage, carrot, cucumber, garlic, or onion [12] and in different plant parts such as seeds, kernels, cultured cells, leaves, stem, roots, or latex [13]. Four different types of chitinases are characterized in plants [8,14-18].

In grapes, chitinases of class I, class III, and class IV were reported $[8,15,16]$. The activity of grape chitinases was detected in various grapevine tissues and was reported to be about ten times higher in berries than in leaves [14] but the data concerning their expression in grape berries are still limited and mostly are connected to special treatments in postharvest manipulation [8] or under direct infections $[14,18]$. However, there are no studies showing natural variability of grape class I chitinase among different grape varieties. Standardly, the class IV of chitinases is connected with the resistance of fungal diseased $[17,19,20]$, but beside the high expression of this class under the biotic attack, in grape berries, class I was reported to be overexpressed, too [8]. Specific class I chitinases are generally basic and vacuolar. Their C-terminal extension of seven amino acids is involved in targeting of the protein to the vacuole and a model for intracellular transport has been reported [21].

Beside their role in resistance, chitinases are the most active protein components in causing wine turbidity $[22,23]$ and those derived from grapes are tolerant to low $\mathrm{pH}$ in juice and wine as well as resistant to photolytic enzymes, as most of the pathogenic related proteins [24-26].

The purpose of this study was to investigate the natural variability of the expression of specific class I chitinase mRNA in grapes of Vitis vinifera L. varieties as well as investigate their antimicrobial activity. Further, the possible effect of chitinase expression in antimicrobial activity was analyzed statistically.

\section{Materials and Methods}

\subsection{Biological Material}

Ripened grapes from different Vitis vinifera L. cultivars produced in the Small Carpathians wine region of Slovakia (Vrbové $48^{\circ} 37^{\prime} 12^{\prime \prime} \mathrm{N}, 17^{\circ} 43^{\prime} 25^{\prime \prime}$ E) were harvested and were transported immediately to the laboratory where they were kept in $-50^{\circ} \mathrm{C}$ until further processing after the surface cleaning. Four red varieties (Alibernet, Dornfelder, Cabernet Sauvignon, Blaufränkisch) and nine white varieties (Sauvignon Blanc, Welschriesling, Weisser Riesling, Irsai Oliver, Pinot Blanc, Pálava, Müller-Thurgau, Grúner Veltliner, Feteasca Regala) were used for RNA extraction and grape pomace (GPE) extracts preparation. All of the analyzed grape varieties are planted within the same small vineyard and all of them were under the same soil, climatic, and stress condition during their grown.

\subsection{RNA Extraction and $c D N A$ Synthesis}

RNA was extracted by the GeneJet Plant RNA Purification Mini Kit (Thermo Fisher Scientific, Waltham, MA, USA) with a small modification of the manufacturer's instruction. A total of $250 \mu \mathrm{g}$ of frozen grape was used. Extracted RNA concentration and A260/A280 nm ratios were determined by Implen NanoPhotometer (München, Germany) and the integrity of the RNA was checked in 1\% agarose gels. Reverse transcription and cDNA synthesis were performed from $20 \mathrm{ng}$ of extracted total RNA using the Tetro cDNA Synthesis Kit (BIOLINE, London, UK) and oligodT primer. 


\subsection{Chitinase Expression Analysis}

A two-step qPCR protocol was used for comparative determination of chitinase mRNA levels where actin (GenBank accession AY847627) was used as the housekeeping gene. Amplification was performed by $5 x$ Hot FirePol EvaGreen (Solis BioDyne, Tartu, Estonia) in Stratagene Mx3005P (Agilent, Santa Clara, CA, USA) under the following cycling conditions: $95^{\circ} \mathrm{C}$ for $2 \mathrm{~min}$ followed by 40 cycles of $95{ }^{\circ} \mathrm{C}-10 \mathrm{~s}, 60^{\circ} \mathrm{C}-40 \mathrm{~s}$, and final analysis of amplicons dissociation curves. Chitinase primers were designed on the base of class I chitinase [8] with checking the specificity in silico as well as for unique fragment amplification.

\subsection{Pomace Extract Preparation}

The pomace extracts were prepared from a portion of the pomace samples $(100 \mathrm{~g})$ immediately freeze-dried after receiving. The samples were extracted with $96 \%$ ethanol at 1:10 ratio $(\mathrm{m} / \mathrm{V})$ under overnight shaking. The extracts were filtered through Whatman No. 2 filter paper to remove unwanted residues. After evaporating off the organic solvent, the filtrates were dissolved in dimethyl sulfoxide (DMSO) at $40 \mathrm{mg} / \mathrm{mL}^{-1}$ as the stock solution and stored at $-20^{\circ} \mathrm{C}$ for further investigation [27].

\subsection{Microorganisms}

In our study, nine strains of microorganisms were tested, including three Gram-positive bacteria Staphylococcus aureus subsp. Aureus CCM 2461, Enterococcus faecalis CCM 4224, and Listeria monocytogenes CCM 4699; three Gram-negative bacteria Escherichia coli CCM 3988, Pseudomonas aeruginosa CCM 1959, and Salmonella enteritidis subsp. enteritidis and the yeasts strains: Candida albicans CCM 8186, Candida glabrata CCM 8270, and Candida tropicalis CCM 8223. All tested strains were collected from the Czech Collection of microorganisms (Brno, Czech Republic). The bacterial suspensions were cultured in the Mueller Hinton broth (MHB, Oxoid, Basingstoke, United Kingdom) at $37^{\circ} \mathrm{C}$ for $24 \mathrm{~h}$ and yeasts were cultured in the Sabouraud dextrose broth (SDB, Oxoid, Basingstoke, UK) at $25^{\circ} \mathrm{C}$ for $24 \mathrm{~h}$.

\subsection{Disc Diffusion Method}

The agar disc diffusion method was used for the determination of antimicrobial activity of the pomace extracts. Briefly, a suspension of the tested microorganism $\left(0.1 \mathrm{~mL}\right.$ of $10^{5}$ cells $\left./ \mathrm{mL}\right)$ was spread onto Mueller Hinton Agar (MHA, Oxoid, Basingstoke, United Kingdom) and Sabouraud dextrose agar (Oxoid, Basingstoke, United Kingdom) at $25^{\circ} \mathrm{C}$. Filter paper discs (6 $\mathrm{mm}$ in diameter) were impregnated with $15 \mu \mathrm{L}$ of the pomace extract and placed on the inoculated plates. Ciprofloxacin $(10 \mu \mathrm{g} / \mathrm{disc})$ and Fluconazole $(25 \mu \mathrm{g} / \mathrm{disc})$ were used as a positive control to determine the sensitivity of the microorganisms under study. The plates were kept at $4{ }^{\circ} \mathrm{C}$ for $2 \mathrm{~h}$ and after incubated aerobically at $37^{\circ} \mathrm{C}$ for $24 \mathrm{~h}$ and $25^{\circ} \mathrm{C}$ for $48 \mathrm{~h}$ for bacteria and yeast, respectively. The diameters of the inhibition zones were measured in millimetres. All the tests were performed in triplicate [28].

\subsection{Determination of Minimum Inhibitory Concentration}

The minimum inhibitory concentration (MIC) is the lowest concentration of the sample that will inhibit the visible growth of microorganisms. Pomace grape extracts were dissolved in DMSO (conc. $20 \mathrm{mg} / \mathrm{mL}$ ). MICs were determined by the microbroth dilution method according to the Clinical and Laboratory Standards Institute recommendation [28] in Mueller Hinton broth (Oxoid) for bacteria and Sabouraud dextrose broth (Oxoid) for yeasts. Briefly, the DMSO extracts solutions were prepared as serial two-fold dilutions to obtain a final concentration ranging from 3.9 to $2000 \mu \mathrm{g} / \mathrm{mL}$. The range of resveratrol concentrations tested was $2-512 \mu \mathrm{g} / \mathrm{mL}$, before the addition of the cells. Each well was then inoculated with microbial suspension at the final density of $0.5 \mathrm{McF}$ arland. After $24 \mathrm{~h}$ incubation at $37^{\circ} \mathrm{C}$ for bacteria and $25^{\circ} \mathrm{C}$ for yeasts, the inhibition of microbial growth was evaluated by measuring the well absorbance at $570 \mathrm{~nm}$ in an absorbance microplate reader Biotek EL808 with shaker (Biotek Instruments, Winooski, VT, USA). The 96 microwell plates were measured before and 
after the experiment. Wells without resveratrol and pomace extract were used as positive controls of growth. Pure DMSO was used as negative control. This experiment was done in eight-replicates for a higher accuracy of the MICs of used pomace grape extracts. The results were expressed in $\mu \mathrm{g} / \mathrm{mL}$ [28].

\subsection{Data Analysis}

A qPCR analysis with the biological triplicates was used in the study and the relative expression values were calculated by the delta delta $\mathrm{Ct}$ method when the expression of specific chitinase was determined as the number of amplification cycles obtained in the reaching of the threshold during the exponential phase of the PCR. Blaufränkish grape variety was used as a comparator in the analysis. Two factor ANOVA with replication and the correlation of antimicrobial activity for individual microorganisms and expression differences of chitinase I gene were performed. All the calculations were prepared and performed in Microsoft Excel for Windows. A parametric two-tailored T-test was performed for obtaining class I chitinase $\mathrm{Ct}$ values [29] using the online platform T-Test Calculator at the significance level 0.05 [30].

\section{Results and Discussion}

The expression profiles of class I chitinase in matured grapes of thirteen different varieties (Alibernet, Dornfelder, Cabernet Sauvignon, Blaufränkisch, Sauvignon Blanc, Welschriesling, Weisser Riesling, Irsai Oliver, Pinot Blanc, Pálava, Müller-Thurgau, Grúner Veltliner, Feteasca Regala) were analyzed by delta delta $\mathrm{Ct}$ method, firstly. Actin was used for the purposes of correction of sample-to-sample differences as an internal control. Both of the amplicons, actin, as well as chitinase I were amplified in a linear mode with reaching the plateau phase. Dissociation curves of both amplicon types returned single melting peak with a Tm of $87^{\circ} \mathrm{C}$ for actin and $86^{\circ} \mathrm{C}$ for grape chitinase I (Figure 1), indicating the specific and unique product.

A
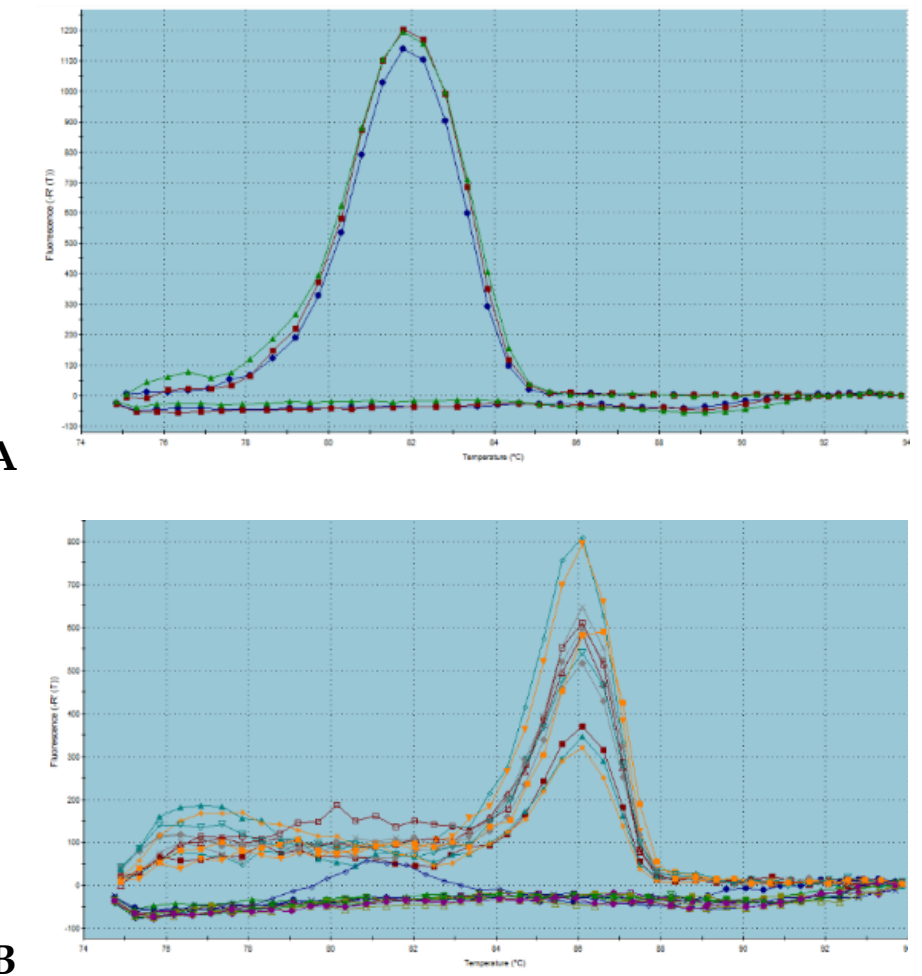

Figure 1. Detection of melting temperatures of generated amplicons of actin (A) and chitinase I (B) gene.

Chitinase I expression (Figure 2) was found to be similar with a very small changes up to the $1 \%$ of overexpression for two of analyzed grape varieties compared to the expression of chitinase I 
in Blaufränkish: Alibernet and Cabernet Savignon. Expression change between 1\% up to the $10 \%$ of overexpression was obtained for the varieties Irsai Oliver, Dornfelder, Pálava, and Welshriesling. In two of the analyzed grape varieties, the expression of chitinase I was significantly higher than in others, in Pinot Blanc matured grapes, it was $51.7 \%$ and in Savignon Blanc, it was $41.72 \%$. In four of the analyzed grape varieties, the underexpression of chitinase I was found: Feteasca Regala $(-5.32 \%)$, Weisser Riesling $(-1.93 \%)$, Grüner Veltliner $(-1.84 \%)$, and Müller Thurgau $(-0.19 \%)$. When comparing the varieties with the lowest and highest expression fold change, they were statistically different in chitinase I mRNA expression at the level of confidence 0.05 with the Tuckey HSD p-value of 0.02 .

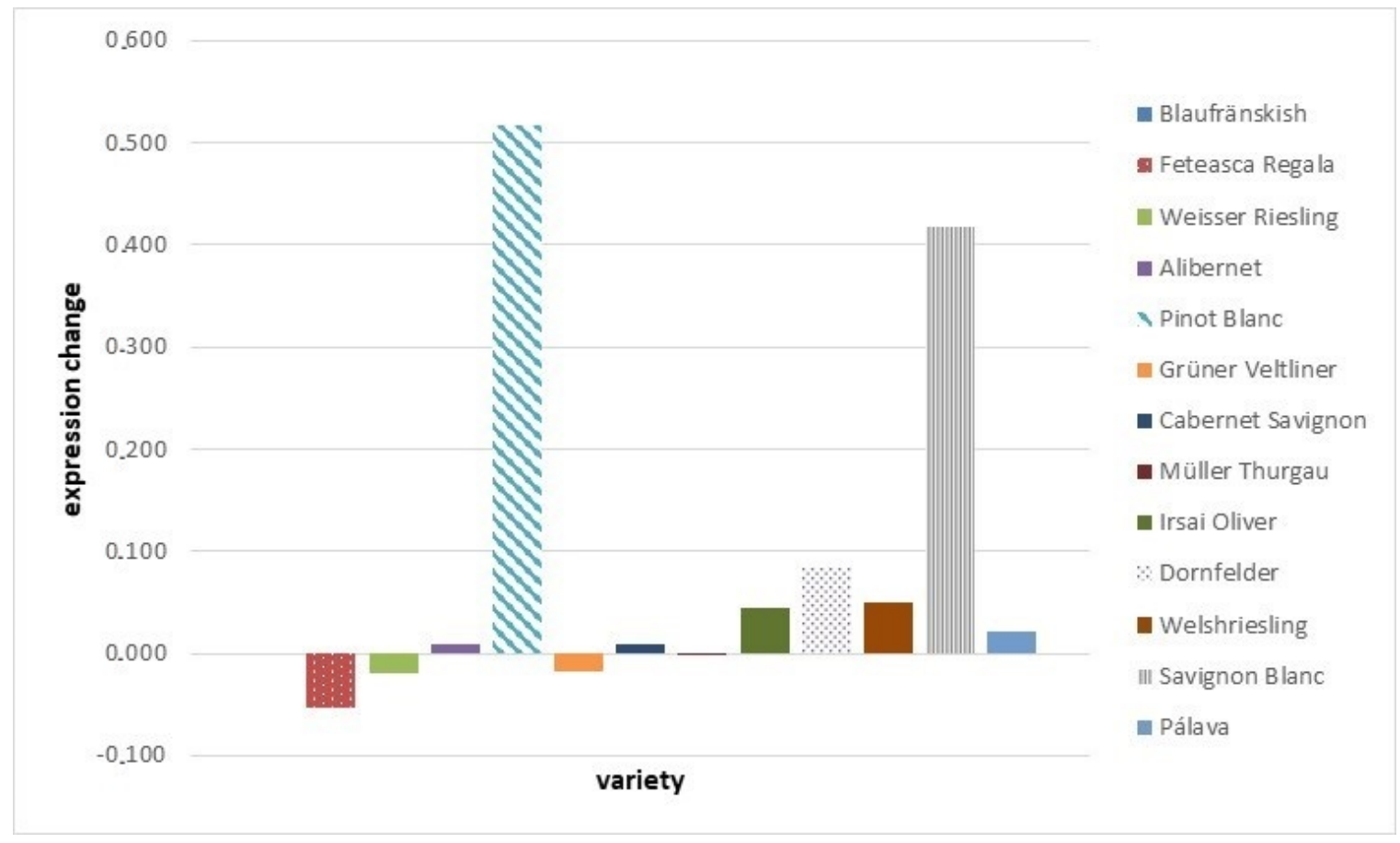

Figure 2. Expression changes of chitinase I gene in grape varieties compared to the Blaufränkish variety.

To date, very limited information exists in literature for grape specific class I chitinase expression and those that exist are in contrary. It was found to be not expressed or to obtain only a faint band after longer exposure in berries of Shiraz, Riesling, Semillon, Muscat Gordo Blanco, Sultana, Pinot Noir, Chardonnay, and Cabernet Savignon by northern blots of total RNA [16]. Another study reported chitinase I as strongly expressed in the roots and stem-internodes, lower expressed in berries, and absent of expression in the leaves [14]. The most recent results of grape class I chitinase in the Cardinal variety under the $\mathrm{CO}_{2}$ pre-treatment show its variable expression in the skin tissues of non-treated grape berries and the accumulation of Vcchit $1 \mathrm{~b}$ transcript during low temperature storage was paralleled by the change in total decay [8].

Using the same matured grapes, antimicrobial activity was investigated further. The diameters of the inhibition zones (in $\mathrm{mm}$ ) corresponding to the tested pomace extracts are shown in Table 1. All assays were carried out in triplicate. Results are expressed as means \pm SD. When regarding individual varieties, different antimicrobial activity was obtained for individual tested microorganisms among themselves with significant differences mainly among bacteria and yeasts data obtained. 
Table 1. Antimicrobial activity of pomace extracts from different varieties in $\mathrm{mm}$.

\begin{tabular}{|c|c|c|c|c|c|c|c|c|c|}
\hline Pomace Sample & EC & PA & SE & EF & LM & SA & CA & CG & CT \\
\hline Alibernet & $8.33 \pm 0.58 \mathrm{a}$ & $8.33 \pm 1.15 b$ & $6.33 \pm 0.58 c$ & $8.33 \pm 1.15 \mathrm{~d}$ & $10.33 \pm 0.58 \mathrm{c}, \mathrm{e}$ & $7.67 \pm 0.58 \mathrm{e}$ & $5.33 \pm 0.58 \mathrm{a}, \mathrm{b}, \mathrm{d}, \mathrm{e}$ & $\begin{array}{c}5.66 \pm 0.58 \\
\text { a,b,d,e }\end{array}$ & $\begin{array}{c}4.33 \pm 0.58 \\
\text { a,b,d,e }\end{array}$ \\
\hline Dornfelder & $9.33 \pm 0.58 \mathrm{a}$ & $8.00 \pm 1.73 b$ & $6.33 \pm 1.15 a$ & $8.67 \pm 1.15 \mathrm{~d}$ & $8.67 \pm 0.58 \mathrm{e}$ & $7.33 \pm 0.58 \mathrm{f}$ & $4.67 \pm 0.58 \mathrm{a}, \mathrm{b}, \mathrm{d}, \mathrm{e}, \mathrm{f}$ & $\begin{array}{c}5.33 \pm 0.58 \\
\text { a,b,d,e }\end{array}$ & $6.67 \pm 0.58 \mathrm{a}$ \\
\hline Cabernet Sauvignon & $7.33 \pm 0.58 \mathrm{a}$ & $6.33 \pm 0.58 b$ & $5.67 \pm 0.58 \mathrm{a}, \mathrm{c}$ & $8.67 \pm 0.58 \mathrm{~b}, \mathrm{c}, \mathrm{d}$ & $7.67 \pm 0.58 \mathrm{c}, \mathrm{e}$ & $6.67 \pm 0.58 \mathrm{~d}, \mathrm{f}$ & $4.33 \pm 0.58 \mathrm{a}, \mathrm{b}, \mathrm{d}, \mathrm{e}, \mathrm{f}$ & $\begin{array}{c}4.67 \pm 0.58 \\
\text { a,b,d,e,f }\end{array}$ & $\begin{array}{l}3.67 \pm 0.58 \\
\mathrm{a}, \mathrm{b}, \mathrm{c}, \mathrm{d}, \mathrm{e}, \mathrm{f}\end{array}$ \\
\hline Blaufränkisch & $8.33 \pm 1.15 \mathrm{a}$ & $6.67 \pm 1.15 b$ & $5.33 \pm 0.58 \mathrm{a}, \mathrm{c}$ & $8.67 \pm 1.15 c, d$ & $9.33 \pm 0.58 \mathrm{~b}, \mathrm{c}, \mathrm{e}$ & $7.33 \pm 0.58 \mathrm{f}$ & $5.33 \pm 0.58 \mathrm{a}, \mathrm{d}, \mathrm{e}$ & $\begin{array}{c}4.33 \pm 0.58 \\
\text { a,d,e,f }\end{array}$ & $\begin{array}{c}4.67 \pm 1.15 \\
\text { a,d,e,f }\end{array}$ \\
\hline Sauvignon Blanc & $6.33 \pm 0.58 \mathrm{a}$ & $7.67 \pm 1.53 \mathrm{~b}$ & $6.33 \pm 1.15 c$ & $8.67 \pm 1.15 \mathrm{~d}$ & $8.67 \pm 0.58 \mathrm{e}$ & $6.67 \pm 0.58 \mathrm{f}$ & $5.67 \pm 1.15 \mathrm{~d}, \mathrm{e}$ & $\begin{array}{c}3.33 \pm 0.58 \\
a, b, c, d, e, f\end{array}$ & $\begin{array}{c}4.33 \pm 0.58 \\
\text { b,d,e }\end{array}$ \\
\hline Welschriesling & $5.67 \pm 0.58 \mathrm{a}$ & $6.00 \pm 1.00 \mathrm{~b}$ & $5.67 \pm 1.15 c$ & $8.67 \pm 0.58 \mathrm{a}, \mathrm{b}, \mathrm{c}, \mathrm{d}$ & $7.33 \pm 0.58 \mathrm{e}$ & $6.33 \pm 1.15 \mathrm{~d}, \mathrm{f}$ & $5.67 \pm 0.58 \mathrm{~d}, \mathrm{~g}$ & $\begin{array}{l}3.33 \pm 0.58 \\
\mathrm{a}, \mathrm{b}, \mathrm{c}, \mathrm{d}, \mathrm{e}, \mathrm{f}, \mathrm{g}\end{array}$ & $\begin{array}{c}2.67 \pm 0.58 \\
\text { a,b,c,d,e,f,g }\end{array}$ \\
\hline Weisser Riesling & $4.67 \pm 0.58 \mathrm{a}$ & $4.67 \pm 0.58 \mathrm{a}, \mathrm{b}$ & $5.33 \pm 0.58 c$ & $9.67 \pm 0.58 \mathrm{a}, \mathrm{b}, \mathrm{c}$ & $6.67 \pm 0.58 \mathrm{a}, \mathrm{e}$ & $7.67 \pm 0.58 \mathrm{a}, \mathrm{c}, \mathrm{e}, \mathrm{f}$ & $4.33 \pm 0.58 \mathrm{~b}, \mathrm{e}, \mathrm{f}$ & $\begin{array}{c}3.67 \pm 0.58 \\
\text { b,c,e,f }\end{array}$ & $\begin{array}{c}3.33 \pm 0.58 \\
\text { b,c,e,f }\end{array}$ \\
\hline Irsai Oliver & $6.33 \pm 0.58 \mathrm{a}$ & $5.67 \pm 0.58 b$ & $6.00 \pm 1.00 c$ & $8.67 \pm 0.58 \mathrm{a}, \mathrm{b}, \mathrm{c}, \mathrm{d}$ & $7.67 \pm 0.58 \mathrm{e}$ & $7.33 \pm 1.15 \mathrm{e}$ & $3.67 \pm 0.58 \mathrm{a}, \mathrm{c}, \mathrm{d}, \mathrm{e}, \mathrm{f}$ & $\begin{array}{c}4.33 \pm 0.58 \\
\text { d,e,f }\end{array}$ & $\begin{array}{c}3.33 \pm 0.58 \\
\mathrm{a}, \mathrm{b}, \mathrm{c}, \mathrm{d}, \mathrm{e}, \mathrm{f}\end{array}$ \\
\hline Pinot Blanc & $5.33 \pm 0.58 \mathrm{a}$ & $4.33 \pm 0.58 \mathrm{~b}$ & $4.67 \pm 0.58 c$ & $7.67 \pm 0.58 \mathrm{a}, \mathrm{b}, \mathrm{c}, \mathrm{d}$ & $6.33 \pm 0.58 \mathrm{~b}, \mathrm{e}$ & $8.33 \pm 0.58 \mathrm{a}, \mathrm{b}, \mathrm{c}, \mathrm{e}, \mathrm{f}$ & $4.67 \pm 0.58 \mathrm{~d}, \mathrm{e}, \mathrm{f}, \mathrm{g}$ & $\begin{array}{c}2.67 \pm 1.15 \\
\text { a,c,d,e,f,g }\end{array}$ & $\begin{array}{c}3.33 \pm 0.58 \\
\text { a,d,e,f }\end{array}$ \\
\hline Pálava & $8.67 \pm 0.58 \mathrm{a}$ & $8.33 \pm 1.15 b$ & $5.33 \pm 1.53 \mathrm{a}, \mathrm{b}, \mathrm{c}$ & $7.67 \pm 0.58 \mathrm{~d}$ & $6.67 \pm 0.58 \mathrm{e}$ & $7.33 \pm 0.58 \mathrm{f}$ & $3.67 \pm 0.58 \mathrm{a}, \mathrm{b}, \mathrm{d}, \mathrm{e}, \mathrm{f}$ & $\begin{array}{c}2.33 \pm 0.58 \\
\mathrm{a}, \mathrm{b}, \mathrm{c}, \mathrm{d}, \mathrm{e}, \mathrm{f}\end{array}$ & $\begin{array}{c}3.33 \pm 0.58 \\
\mathrm{a}, \mathrm{b}, \mathrm{d}, \mathrm{e}, \mathrm{f}\end{array}$ \\
\hline Müller-Thurgau & $7.67 \pm 0.58 \mathrm{a}$ & $6.33 \pm 0.58 \mathrm{~b}$ & $4.33 \pm 0.58 \mathrm{a}, \mathrm{c}$ & $7.67 \pm 0.58 \mathrm{c}, \mathrm{d}$ & $5.67 \pm 1.15 \mathrm{e}$ & $6.33 \pm 0.58 \mathrm{f}$ & $3.33 \pm 1.15 \mathrm{a}, \mathrm{b}, \mathrm{d}, \mathrm{f}$ & $\begin{array}{c}3.67 \pm 1.15 \\
\mathrm{a}, \mathrm{b}, \mathrm{d}, \mathrm{f}\end{array}$ & $\begin{array}{c}2.33 \pm 0.58 \\
\mathrm{a}, \mathrm{b}, \mathrm{d}, \mathrm{e}, \mathrm{f}\end{array}$ \\
\hline Grúner Veltliner & $5.67 \pm 0.58 \mathrm{a}$ & $6.33 \pm 0.58 b$ & $4.33 \pm 0.58 \mathrm{~b}, \mathrm{c}$ & $8.00 \pm 1.00 \mathrm{a}, \mathrm{c}, \mathrm{d}$ & $6.33 \pm 0.58 \mathrm{c}, \mathrm{e}$ & $7.33 \pm 0.58 \mathrm{c}, \mathrm{f}$ & $4.67 \pm 0.58 \mathrm{~d}, \mathrm{f}, \mathrm{g}$ & $\begin{array}{c}3.33 \pm 0.58 \\
\mathrm{a}, \mathrm{b}, \mathrm{d}, \mathrm{e}, \mathrm{f}\end{array}$ & $\begin{array}{c}2.67 \pm 0.58 \\
\text { a,b,d,e,f,g }\end{array}$ \\
\hline Feteasca Regala & $6.33 \pm 1.15 \mathrm{a}$ & $5.67 \pm 0.58 \mathrm{~b}$ & $4.33 \pm 0.58 \mathrm{c}$ & $8.67 \pm 0.58 b, c, d$ & $7.67 \pm 1.15 \mathrm{c}, \mathrm{e}$ & $7.00 \pm 1.00 \mathrm{c}, \mathrm{f}$ & $4.67 \pm 1.15 \mathrm{~d}, \mathrm{e}$ & $\begin{array}{c}4.33 \pm 0.58 \\
\mathrm{~d}, \mathrm{e}, \mathrm{f}\end{array}$ & $\begin{array}{c}3.67 \pm 0.58 \\
\mathrm{a}, \mathrm{d}, \mathrm{e}, \mathrm{f}\end{array}$ \\
\hline
\end{tabular}

SA-Staphylococcus aureus subsp. aureus, EF-Enterococcus faecalis, LM-Listeria monocytogenes, EC-Escherichia coli, PA-Pseudomonas aeruginosa, SE-Salmonella enteritidis subsp. enteritidis, CA-Candida albicans, CG-Candida glabrata, Candida tropicalis; different letters in each row indicate the statistically significant differences among the antimicrobial activity data for tested microorganisms. 
Both factors, microorganism specie as well as grape variety, were returned in two factor ANOVA as a significant effect in antimicrobial activity (Table 2 ) at the level 0.05 . The most inhibitory activity of GPE was found against Listeria monocytogenes, which corresponds to the results where a strong inhibitory effect against Listeria monocytogenes has been found by grape juice and grape extracts derived from Vitis vinifera variety "Ribier" [31].

Table 2. ANOVA results for tested grape varieties and antimicrobial activity.

\begin{tabular}{ccccccc}
\hline Source of Variation & SS & df & MS & F & $p$-Value & F Crit \\
\hline Sample & 138.4729 & 12 & 11.53941 & 19.19589 & $9.78321 \times 10^{-29}$ & 1.793719 \\
\hline Columns & 896.7407 & 8 & 112.0926 & 186.4668 & $5.40308 \times 10^{-97}$ & 1.978112 \\
\hline Interaction & 196.2963 & 96 & 2.044753 & 3.401461 & $1.70267 \times 10^{-14}$ & 1.314387 \\
\hline Within & 140.6667 & 234 & 0.60114 & & & \\
\hline Total & 1372.177 & 350 & & & & \\
\hline
\end{tabular}

The minimum inhibitory concentration that was count as is the lowest concentration of the sample that will inhibit the visible growth of microorganisms are summarized in Table 3.

Table 3. Minimal inhibition concentration of pomace extract in $\mu \mathrm{g} / \mathrm{mL}$.

\begin{tabular}{cccccccccc}
\hline Grape Sample & EC & PA & SE & EF & LM & SA & CA & CG & CT \\
\hline Alibernet & 500 & 1000 & 1000 & 500 & 250 & 125 & 1000 & 1000 & 1000 \\
\hline Dornfelder & 500 & 500 & 1000 & 500 & 250 & 250 & 1000 & 2000 & 500 \\
\hline Cabernet Sauvignon & 250 & 500 & 500 & 500 & 500 & 250 & 1000 & 2000 & 500 \\
\hline Blaufränkisch & 500 & 1000 & 500 & 500 & 1000 & 125 & 2000 & 1000 & 500 \\
\hline Sauvignon Blanc & 500 & 1000 & 1000 & 1000 & 500 & 500 & 2000 & 2000 & 2000 \\
\hline Welschriesling & 1000 & 1000 & 1000 & 1000 & 250 & 500 & 1000 & 2000 & 1000 \\
\hline Weisser Riesling & 1000 & 500 & 1000 & 1000 & 500 & 500 & 2000 & 2000 & 2000 \\
\hline Irsai Oliver & 250 & 500 & 1000 & 1000 & 250 & 500 & 2000 & 1000 & 2000 \\
\hline Pinot Blanc & 500 & 500 & 1000 & 500 & 250 & 500 & 2000 & 2000 & 1000 \\
\hline Pálava & 500 & 1000 & 1000 & 500 & 250 & 500 & 1000 & 2000 & 2000 \\
\hline Müller-Thurgau & 1000 & 1000 & 1000 & 500 & 250 & 250 & 2000 & 2000 & 2000 \\
\hline Grüner Veltliner & 1000 & 500 & 500 & 1000 & 500 & 250 & 1000 & 2000 & 2000 \\
\hline Feteasca Regala & 1000 & 1000 & 500 & 500 & 500 & 500 & 1000 & 2000 & 1000 \\
\hline
\end{tabular}

SA-Staphylococcus aureus subsp. aureus, EF-Enterococcus faecalis, LM-Listeria monocytogenes, EC-Escherichia coli, PA-Pseudomonas aeruginosa, SE-Salmonella enteritidis subsp. enteritidis, CA-Candida albicans, CG-Candida glabrata, CT-Candida tropicalis.

Finally, possible correlations among the levels of class I chitinase and antimicrobial activity against individual microorganisms were inspected by MS Excel using the appropriate statistical formulas with the results of correlation coefficients listed in Table 4. For most of the analyzed species, no correlation was found (these are not shown graphically), but in the case of Staphylococcus aureus (Figure 3) and Candida albicans (Figure 4), a weak positive correlation occurred and in the case of Candida glabrata (Figure 5), a negative correlation with a weak relationship between variables. 
Table 4. Correlation coefficients for individual antimicrobial activity to the expression levels of chitinase I gene in analyzed grape varieties.

\begin{tabular}{cc}
\hline Antimicrobial Activity & $\boldsymbol{R}$ Correlation to the Chitinase mRNA Expression \\
\hline Escherichia coli & -0.264 \\
\hline Pseudomonas aeruginosa & -0.154 \\
\hline Salmonella enteritidis subsp. enteritidis & 0.145 \\
\hline Enterococcus faecalis & -0.251 \\
\hline Listeria monocytogenes & -0.036 \\
\hline Staphylococcus aureus subsp. aureus & 0.300 \\
\hline Candida albicans & 0.296 \\
\hline Candida glabrata & -0.393 \\
\hline Candida tropicalis & 0.111 \\
\hline
\end{tabular}

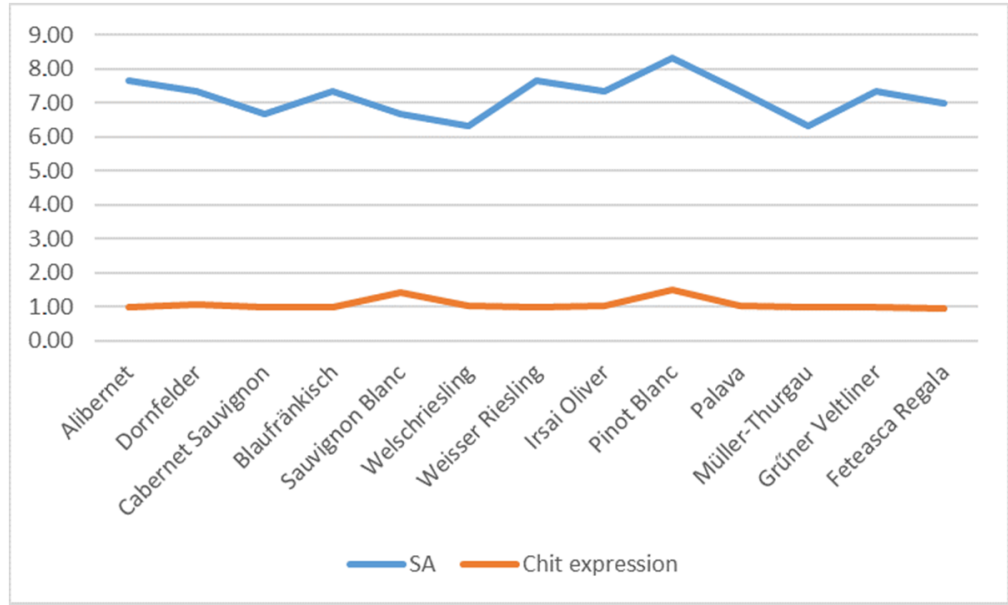

Figure 3. Staphylococcus aureus subsp. aureus (SA) vs. chitinase expression (Chit) comparison.

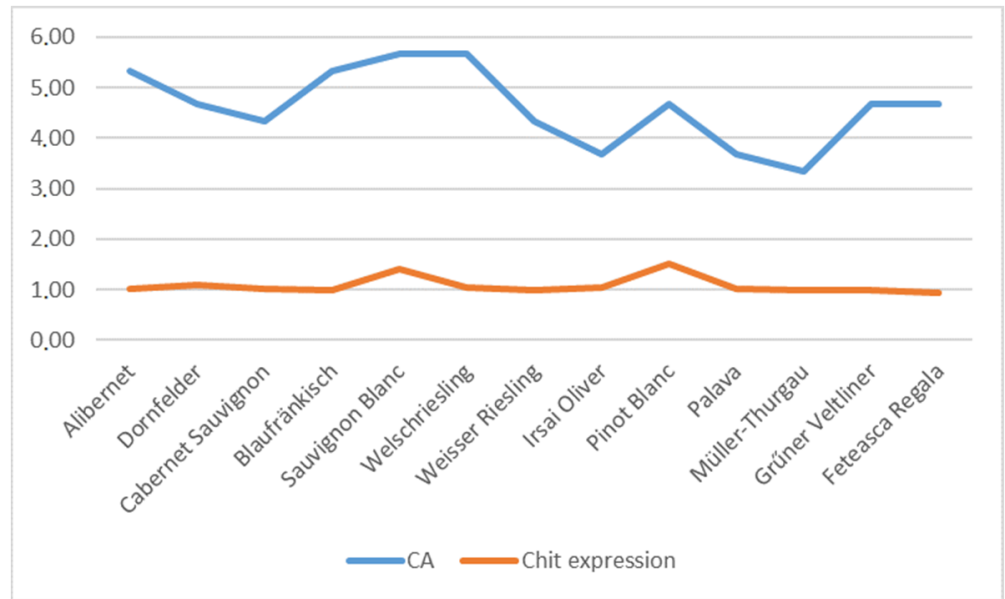

Figure 4. Candida albicans vs. chitinase expression comparison. 


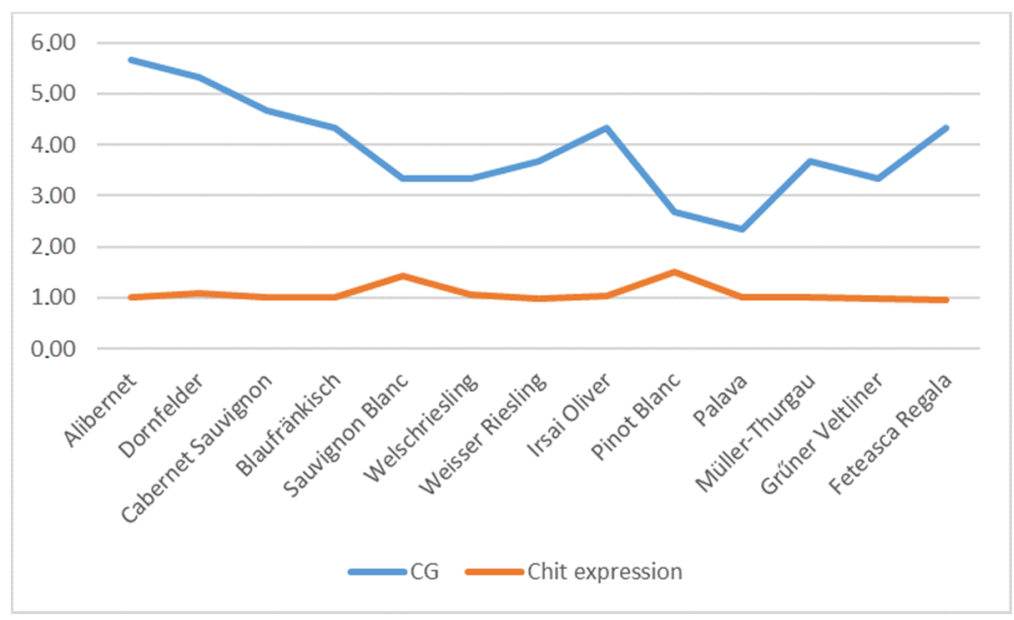

Figure 5. Candida glabrata vs. chitinase expression comparison.

Only a few chitinases are reported in the literature as proteins with antimicrobial effect [32]. Chitinases were found in many of the organisms, including seed plants such as Carica papaya [33], Arachis hypogaea [34], and Hevea brasiliensis [35]. In the case of Arachis hypogaea, antimicrobial activity against Staphylococcus aureus was described, similar to our results, [36] and chitinases of Carica papaya exhibited antibacterial activity towards E. coli [33]. Class I basic chitinase, which is reported in literature to be generally more antifungal in nature compared to other chitinase classes, is present in vacuoles [35]. Validation of the occurrence of chitinase activity in berry skin extracts was performed and confirmed previously [37]. The present study has demonstrated that GPEs were effective against Gram-positive, Gram-negative bacteria and yeasts. Red wine has been shown to prevent damage to the gastric mucosa induced by Helicobacter pylori, possibly through inhibition of the vacA gene [38]. Another study [39] demonstrated that grape seed extracts have antimicrobial potential, Gram-positive bacteria being more sensitive than Gram-negative bacteria. Our study has also demonstrated that Gram-positive strains were more susceptible to GPE compared with Gram-negative bacteria and yeasts. Recently, it has been reported [40] an antibacterial effect of grape pomace extracts mainly against $S$. aureus and E. coli: the activity was directly related to the polar phenolic content. Grape seed extracts obtained from wine and table cultivars of Vitis vinifera L. were found to be active against Candida albicans and their activity was related to the presence of polymeric flavan-3-ols [41].

\section{Conclusions}

In this work, a first study of natural variability of expression of grape class I chitinase mRNA levels were analyzed among thirteen different Vitis vinifera $\mathrm{L}$ varieties as well as antimicrobial activity of their matured berries. Our results indicate, that the expression of the class I chitinase gene is stable among the grape varieties. However, in two of the analyzed varieties, it was expressed higher. Further, it has been demonstrated that grape pomace extracts were effective against Gram-positive, Gram-negative bacteria and yeasts in the case of analyzed varieties and for antimicrobial activity against Staphylococcus aureus susbp. aureus, Candida albicans, and Candida glabrata, weak correlation tendency was found. Further analysis is needed to ascertain the tendencies as well as define it more specifically.

Author Contributions: J.Ž. and M.K. were responsible for the design of the study; J.S., J.Ž. and M.K. conducted the study and collected the samples. L.Z., J.B., V.F., J.S. and S.K. performed the laboratory analysis. J.Ž., L.Z. and M.K. were responsible for writing and editing the manuscript. All authors have read and agreed to the published version of the manuscript.

Funding: This research was funded by the grants of Agentúra na Podporu Výskumu a Vývoja, grant number APVV SK-BY-RD-19-0014 "The formulation of novel compositions and properties study of the polysaccharides based edible films and coatings with antimicrobial and antioxidant plant additives". 
Acknowledgments: The research leading to these results has received funding from the European Community under project no. 26220220180: Building Research Centre "AgroBioTech" and VEGA 1/0180/20.

Conflicts of Interest: The authors declare no conflict of interest.

\section{References}

1. Pastorello, E.A.; Farioli, L.; Pravettoni, V.; Ortolani, C.; Fortunato, D.; Giuffrida, M.G.; Garoffo, L.P.; Calamari, A.M.; Brenna, O.; Conti, A. Identification of grape and wine allergens as an Endochitinase 4, a lipid-transfer protein, and a Thaumatin. J. Allergy Clin. Immunol. 2003, 111, 350-359. [CrossRef] [PubMed]

2. Soural, I.; Balik, J.; Vrchotová, N.; Triska, J. Varietal Distributions of Stilbenes in Grape Cane of Vitis vinifera L. Acta Hortic. Regiotect. 2017, 20, 11-14. [CrossRef]

3. Arora, P.; Ansari, S.H.; Najmi, A.K.; Anjum, V.; Ahmad, S. Investigation of anthi-asthmatic potential of dried fruits of Vitis vinifera L. in animal model of bronchial asthma. Allerg. Asthma Clin. Immunol. 2016, 12, 42. [CrossRef] [PubMed]

4. Ahmad, F.; Khan, G.M. Study of Aging and Hepatoprotective Activity of Vitis vinifera L. Seeds in Albino Rats. Asian Pac. J. Trop. Biomed. 2012, 2, 1770-1774. [CrossRef]

5. Masani, Y.A.; Mathew, N.; Chakraborty, M.; Kamath, J.V. Effects of Vitis vinifera against Trition X 100 induced hyperlipidaemia in rats. Int. Res. J. of Pharm. 2012, 3, 101-103.

6. Glasa, M.; Predajňa, L.; Sihelská, N.; Šoltys, K.; Ruiz-García, A.-B. Analysis of Virome by High-Throughput Sequencing Revealed Multiple Infection and Intra-Virus Diversity in a Single Grapevine Plant. Acta Hortic. Regiotect. 2020, 23, 35-39. [CrossRef]

7. Iandolino, A.; Nobuta, K.; da Silva, F.G.; Cook, D.R.; Meyers, B.C. Comparative expression profiling in grape (Vitis vinifera) berries derived from frequency analysis of ESts and MPSS signatures. BMC Plant Biol. 2008, 8, 53. [CrossRef]

8. Romero, I.; Sanchez-Ballesta, M.T.; Maldonado, R.; Escribano, M.I.; Merodio, C.; Sanchez-Ballesta, M.T. Expression of class I chitinase and $\beta-1,3$-glucanase genes and postharvest fungal decay control of table grapes by high CO2 pretreatment. Postharvest Boil. Technol. 2006, 41, 9-15. [CrossRef]

9. Dean, R.; Van Kan, J.A.; Pretorius, Z.A.; Hammond-Kosack, K.E.; Di Pietro, A.; Spanu, P.D.; Rudd, J.J.; Dickman, M.; Kahmann, R.; Ellis, J.; et al. The top 10 fungal pathogens in molecular plant pathology. Mol. Plant Pathol. 2012, 13, 414-430. [CrossRef]

10. Smith, R.S.; Osburn, R.M. Combined Used of Lipo-Chitooligosaccharides and Chitinous Compounds for Enhanced Plant Growth and Yield. U.S. Patent 9,253,989 B2, 9 February 2016.

11. Collinge, D.B.; Kragh, K.M.; Mikkelsen, J.D.; Nielsen, K.K.; Rasmussen, U.; Vad1, K. Plant chitinases. Plant J. 1993, 3, 31-40. [CrossRef]

12. Kumar, M.; Brar, A.; Yadav, M.; Chawade, A.; Vivekanand, V.; Pareek, N. Chitinases-Potential Candidates for Enhanced Plant Resistance towards Fungal Pathogens. Agriculture 2018, 8, 88. [CrossRef]

13. Malik, A. Preety Purification and properties of plant chitinases: A review. J. Food Biochem. 2019, 43, e12762. [CrossRef]

14. Derckel, J.-P.; Legendre, L.; Audran, J.-C.; Haye, B.; Lambert, B. Chitinases of the grapevine (Vitis vinifera L.): Five isoforms induced in leaves by salicylic acid are constitutively expressed in other tissues. Plant Sci. 1996, 119, 31-37. [CrossRef]

15. Ano, A.; Takayanagi, T.; Uchibori, T.; Okuda, T.; Yokotsuka, K. Characterization of a class III chitinase from Vitis vinifera cv. Koshu. J. Biosci. Bioeng. 2003, 95, 645-647. [CrossRef]

16. Robinson, S.P.; Jacobs, A.K.; Dry, I.B. A class IV chitinase is highly expressed in grape berries during ripening. Plant. Physiol. 1997, 114, 771-778. [CrossRef]

17. Vincenzi, S.; Bierma, J.; Wickramasekara, S.I.; Curioni, A.; Gazzola, D.; Bakalinsky, A. Characterization of a Grape Class IV Chitinase. J. Agric. Food Chem. 2014, 62, 5660-5668. [CrossRef]

18. Farshidi, N.; Moghaddam, M.; Yaghoubi, V.; Ayati, S.H.; Varasteh, A.R.; Sankian, M. Type IV chitinase quantification in four different grape cultivars (Vitis vinifera) in northeast of Iran by an indirect sandwich enzyme-linked immunosorbent assay. J. Immunoass. Immunochem. 2018, 40, 139-148. [CrossRef]

19. Trotel-Aziz, P.; Couderchet, M.; Vernet, G.; Aziz, A. Chitosan Stimulates Defense Reactions in Grapevine Leaves and Inhibits Development of Botrytis Cinerea. Eur. J. Plant Pathol. 2006, 114, 405-413. [CrossRef] 
20. Saito, S.; Odagiri, M.; Furuya, S.; Suzuki, S.; Takayanagi, T. Inhibitory effect of chitinases isolated from Semillon grapes (Vitis vinifera) on growth of grapevine pathogens. J. Plant Biochem. Biotechnol. 2011, 20, 47-54. [CrossRef]

21. Punja, Z.K.; Zhang, Y.-Y. Plant Chitinases and Their Roles in Resistance to Fungal Diseases. J. Nematol. 1993, 25, 526-540.

22. Falconer, R.; Marangon, M.; Van Sluyter, S.C.; Neilson, K.A.; Chan, C.; Waters, E.J. Thermal Stability of Thaumatin-Like Protein, Chitinase, and Invertase Isolated from Sauvignon blanc and Semillon Juice and Their Role in Haze Formation in Wine. J. Agric. Food Chem. 2010, 58, 975-980. [CrossRef]

23. Marangon, M.; Van Sluyter, S.C.; Neilson, K.A.; Chan, C.; Haynes, P.A.; Waters, E.J.; Falconer, R. Roles of Grape Thaumatin-like Protein and Chitinase in White Wine Haze Formation. J. Agric. Food Chem. 2011, 59, 733-740. [CrossRef]

24. Ferreira, R.B.; A Piçarra-Pereira, M.; Monteiro, S.A.; Loureiro, V.B.; Teixeira, A.R. The wine proteins. Trends Food Sci. Technol. 2001, 12, 230-239. [CrossRef]

25. Van Sluyter, S.C.; McRae, J.; Falconer, R.; Smith, P.; Bacic, A.; Waters, E.J.; Marangon, M. Wine Protein Haze: Mechanisms of Formation and Advances in Prevention. J. Agric. Food Chem. 2015, 63, 4020-4030. [CrossRef] [PubMed]

26. Waters, E.; Alexander, G.; Muhlack, R.; Pocock, K.; Colby, C.; O’Neill, B.; Høj, P.; Jones, P. Preventing protein haze in bottled white wine. Aust. J. Grape Wine Res. 2005, 11, 215-225. [CrossRef]

27. Kunová, S.; Felšöciová, S.; Tvrda, E.; Ivanišová, E.; Kántor, A.; Žiarovská, J.; Terentjeva, M.; Kačániová, M. Antimicrobial activity of resveratrol and grape pomace extract. Potravinarstvo Slovak J. Food Sci. 2019, 13, 363-368. [CrossRef]

28. Clinical and Laboratory Standards Institute (CLSI). Performance Standards for Antimicrobial Susceptibility Testing, 29th ed.; CLSI Supplement M100; Clinical and Laboratory Standards Institute: Wayne, PA, USA, 2019.

29. Smyth, G.K. Linear Models and Empirical Bayes Methods for Assessing Differential Expression in Microarray Experiments. Stat. Appl. Genet. Mol. Boil. 2004, 3, 1-25. [CrossRef] [PubMed]

30. Social Science Statistics. T-Test Calculator for 2 Independent Means. 2019. Available online: www. socscistatistics.com/tests/studentttest (accessed on 10 June 2020).

31. Rhodes, P.; Mitchell, J.; Wilson, M.; Melton, L. Antilisterial activity of grape juice and grape extracts derived from Vitis vinifera variety Ribier. Int. J. Food Microbiol. 2006, 107, 281-286. [CrossRef] [PubMed]

32. De Medeiros, S.C.; Júnior, J.E.M.; Sales, G.W.P.; Grangeiro, T.B.; Nogueira, N.A.P. Chitinases as Antibacterial Proteins: A Systematic Review. J. Young- Pharm. 2018, 10, 144-148. [CrossRef]

33. Chen, Y.-T.; Hsu, L.-H.; Huang, I.-P.; Tsai, T.-C.; Lee, G.-C.; Shaw, J.-F. Gene Cloning and Characterization of a Novel Recombinant Antifungal Chitinase from Papaya (Carica papaya). J. Agric. Food Chem. 2007, 55, 714-722. [CrossRef]

34. Wang, S.; Shao, B.; Rao, P.; Lee, Y.; Ye, X. Hypotin, a Novel Antipathogenic and Antiproliferative Protein from Peanuts with a Sequence Similar to Those of Chitinase Precursors. J. Agric. Food Chem. 2007, 55, 9792-9799. [CrossRef] [PubMed]

35. Van Scheltinga, A.C.T.; Hennig, M.; Dijkstra, B.W. The 1.8 Å Resolution Structure of Hevamine, a Plant Chitinase/Lysozyme, and Analysis of the Conserved Sequence and Structure Motifs of Glycosyl Hydrolase Family 18. J. Mol. Biol. 1996, 262, 243-257. [CrossRef] [PubMed]

36. Filippi, A.; Petrussa, E.; Boscutti, F.; Vuerich, M.; Vrhovsek, U.; Rabiei, Z.; Braidot, E. Bioactive Polyphenols Modulate Enzymes Involved in Grapevine Pathogenesis and Chitinase Activity at Increasing Complexity Levels. Int. J. Mol. Sci. 2019, 20, 6357. [CrossRef] [PubMed]

37. An, B.J.; Kwak, J.-H.; Son, J.-H.; Park, J.-M.; Lee, J.-Y.; Jo, C.; Byun, M.-W. Biological and anti-microbial activity of irradiated green tea polyphenols. Food Chem. 2004, 88, 549-555. [CrossRef]

38. Grover, A.; Yashpal; Sen, A.; Arora, N.; Kirti, P.B.; Sharma, R.P. Removal of Vacuolar Targeting Signal from Class I Vacuolar Chitinase leads to its Extracellular Secretion in Transgenic Tobacco. J. Plant Biochem. Biotechnol. 2001, 10, 139-142. [CrossRef]

39. Ruggiero, P.; Rossi, G.; Tombola, F.; Pancotto, L.; Lauretti, L.; Del Giudice, G.; Zoratti, M. Red wine and green tea reduce H pylori- or VacA-induced gastritis in a mouse model. World J. Gastroenterol. 2007, 13, 349. [CrossRef] 
40. Ja Jayaprakasha, G.; Selvi, T.; Sakariah, K. Antibacterial and antioxidant activities of grape (Vitis vinifera) seed extracts. Food Res. Int. 2003, 36, 117-122. [CrossRef]

41. Simonetti, G.; Santamaria, A.R.; D’Auria, F.; Mulinacci, N.; Innocenti, M.; Cecchini, F.; Pericolini, E.; Gabrielli, E.; Panella, S.; Antonacci, D.; et al. Evaluation of Anti-Candida Activity of Vitis vinifera L. Seed Extracts Obtained from Wine and Table Cultivars. BioMed Res. Int. 2014, 2014, 1-11. [CrossRef]

(C) 2020 by the authors. Licensee MDPI, Basel, Switzerland. This article is an open access article distributed under the terms and conditions of the Creative Commons Attribution (CC BY) license (http://creativecommons.org/licenses/by/4.0/). 